\title{
Impacts of Industry Towards the Structure of Customary Land Tenure on the Natural Sago Forest in Imekko, Sorong Selatan Regency-West Papua
}

\author{
Mecky Sagrim \\ Department of Social Economic of Agriculture, Agricultural Faculty, Papua University, Manokwari, Indonesia
}

Email address:

meckysagrim@yahoo.com

To cite this article:

Mecky Sagrim. Impacts of Industry Towards the Structure of Customary Land Tenure on the Natural Sago Forest in Imekko, Sorong Selatan Regency-West Papua. Agriculture, Forestry and Fisheries. Vol. 5, No. 5, 2016, pp. 135-140. doi: 10.11648/j.aff.20160505.11

Received: July 15, 2016; Accepted: July 25, 2016; Published: August 12, 2016

\begin{abstract}
The goal of the research is to assess structural dynamics of customary land tenure in Imeko communities as a result of emergence regarding the operations of PT ANJ-AgriPapua and PerumPerhutani in Sorong Selatan Regency. The objectives are as follows: (1) to identify and map the structure of customatyland tenure rightsover the Natural Sago Forest (NSF) in Imekko; (2) to identify and mapstuructural dynamics of customary land tenure on the NSF in relation with the emergence of PT ANJ-Agri Papua and PerumPerhutani in Imekko. The research reveals that the customary land tenure exists under communal and collective ownership with regard to keret/fam (family names). Local communities are entitled with rights to access, collect forest products, use, control, manage, transfer and release, reclaim, and own their land. Individuals who do not have rights over the customary land are able to acquire ownership after obtaining permission with or without compensation on the line. In the case of Dusun Sagu, ownership belongs to family groups (member of nuclear family). Inheritanceon the NSF and Dusun Sagu are passed downtosons, or to the keret/fam, heirsof the family who cultivated the land. Moreover, the research finds that the structures of customary land tenure among Imekko communities are changing due to the emergence of PT ANJAgri Papua and Perum Perhutani in the area. From the eight rights that have been practiced for generations, only three rights remain: rights for limited access, use, and collecting forest products in the concession area of the factories. The community groups are supported to utilize these rights in order to meet their basics needs as well as and to generate income through forest utilization.
\end{abstract}

Keywords: Land Tenure, Industries, Local Community, Natural Sago Forest, Papua

\section{Introduction}

Interactions between humans and natures (land, forest, etc.) are mutual $[10,16]$. Sustainability of natural resources isinfluenced by the structure of tenure rights in communities who live close to the resources. In line with this, implementations of such structure are affected by the availability of natural resources [12]; [2]. Humans, in fact, play a central position in this regard.

Land disputes in Indonesia are common, particularly inequality in land use rights. Land-related conflicts such as land tenure exists from thelaten to more obvious ones $[16,8$, 1]. Problems on tenure rights overNatural Sago Forest (NSF) are just some of manyobserved in the country. The NSF is asource of livelyhood forcommunities becauseit provides food and industrial materials $[16,4,3]$. Sago is a type of palm tree that grows in swamp areas with low soil $\mathrm{pH}$. It is commonly known as staple food ofindigenous people in the eastern part of Indonesia, especially the Mollucans and the Papuans. In Sumatra and Sulawesi, sago is not staple but complementary food, and is alsoused for industry. In Java, sago starch is used as raw material for industry, for example to make noodle, spagetti and macaroni. Meanwhile, In Japan, it is used to make biodegradable film, high fructose syrup and alcohol [5].

Indonesia is noted to have the largest sago areas with aproximatelly $51.30 \%$ of the total of 2.2 million ha of the world's sago forests. It is followed by Papua New Guinea (43.3\%), Malaysia (1.5\%) and Thailand (0.2\%) [6]. According to [4] withhis interpretation of a satelite image, 
Sago forest covers approximately $1,528,000$ ha on the peatland in Indonesia. In fact, it is reported that the highest sago forest area (approximately 90\%) is located in Papua. Sago forest area in Sorong Selatan covers approximately $149,7778,42$ ha in Imekko region: Inanwatan, Metemani, Kais and Kokoda [7, 15].

Ownership of land rights and property rights (forest products, rangelands, marshlands, and uncultivated lands) on the NSFin Imekko belongs tothe indigenous peoples of Iwaro, Kaiso, Awee, Moge, Medewana, and Maybrat. The NSF, in fact, has beengaining interest from investors such as PT Austindo Nusantara Jaya (ANJ)-Agri Papua with 40,000 ha, and Perusahaan Umum (Perum) Perhutani with 16,055 ha of concession area $[6,7]$. It is suggested that the emergence of the two factories have contributed to the chage of the structures of customary (adat) land tenure of the communities.

In brief, the goal of this research is to assessstructural dynamics of the customary land tenure in Imekko communitiesin driven by the emergence ofPT ANJ-Agri Papua and Perum Perhutani operations. The objectives of this research are by identifying and mapping the structure of customary land tenure rights over the NSF in Imekko and structural dynamics of customary land tenure on the NSF in relation with the emergence of PT ANJ-Agri Papua and Perum Perhutani in Imekko.

\section{Methods}

The research was conducted in four districts: Inanwatan, Metemani, Kais, and Kokoda (Imekko) of Sorong Selatan Regency, Papua Barat Province. These are significant locations to focus on because: (a) the NSF is located in these districts - locations of the factories; (b) the communities living in these areas are originally under the customary land law the owners of the land rights over the NSF. They eventuallyexperience changes in customary land tenure rights as being 'pressurized' by sago industries, namely PT ANJAgri Papua and PerumPerhutani.

Land rights owners of the locations include eight local etnics, residing in four districts as shown below.

Table 1. List of villages based on the ethnic groups and disctricts in Imekko (focus area of the research).

\begin{tabular}{llll}
\hline District & \multicolumn{2}{l}{ Village } & Ethnic groups \\
\hline \multirow{2}{*}{ Inanwatan } & 1. & Sibae & Sowabau \\
& 2. & Isogo & Sowabau \\
Metemani & 1. & Puragi & Iwaro \\
& 2. & Mugim & Muge \\
\multirow{2}{*}{ Kais } & 1. & Sumano I & Awee \\
& 2. & Kais & Kaiso \\
\multirow{2}{*}{ Kokoda } & 3. & Mogatemin & Maybrat \\
& 1. & Tarof & Amee \\
\hline
\end{tabular}

The research adopted purposive sampling in identifing and choosing respondents whose lands are occupied by the factories. The communities are experiencingchanges in the structure of customary land tenure due to the factories' emergence in the NSF. In addition, the fact that some government officials lack of competency in decision making regarding regulationon land use rights have supported this trend. This research chose 55 key respondents and 36 casebased respondents. In total, there were 91 respondents who originally come from and live in villages in Imekko. According to [11]; and [10], qualitative research requires data collection to be gathered under a natural setting, and based upon primary data source. Meanwhile, techniques used for collecting data made based on participant observation, interview, and indepth interview.

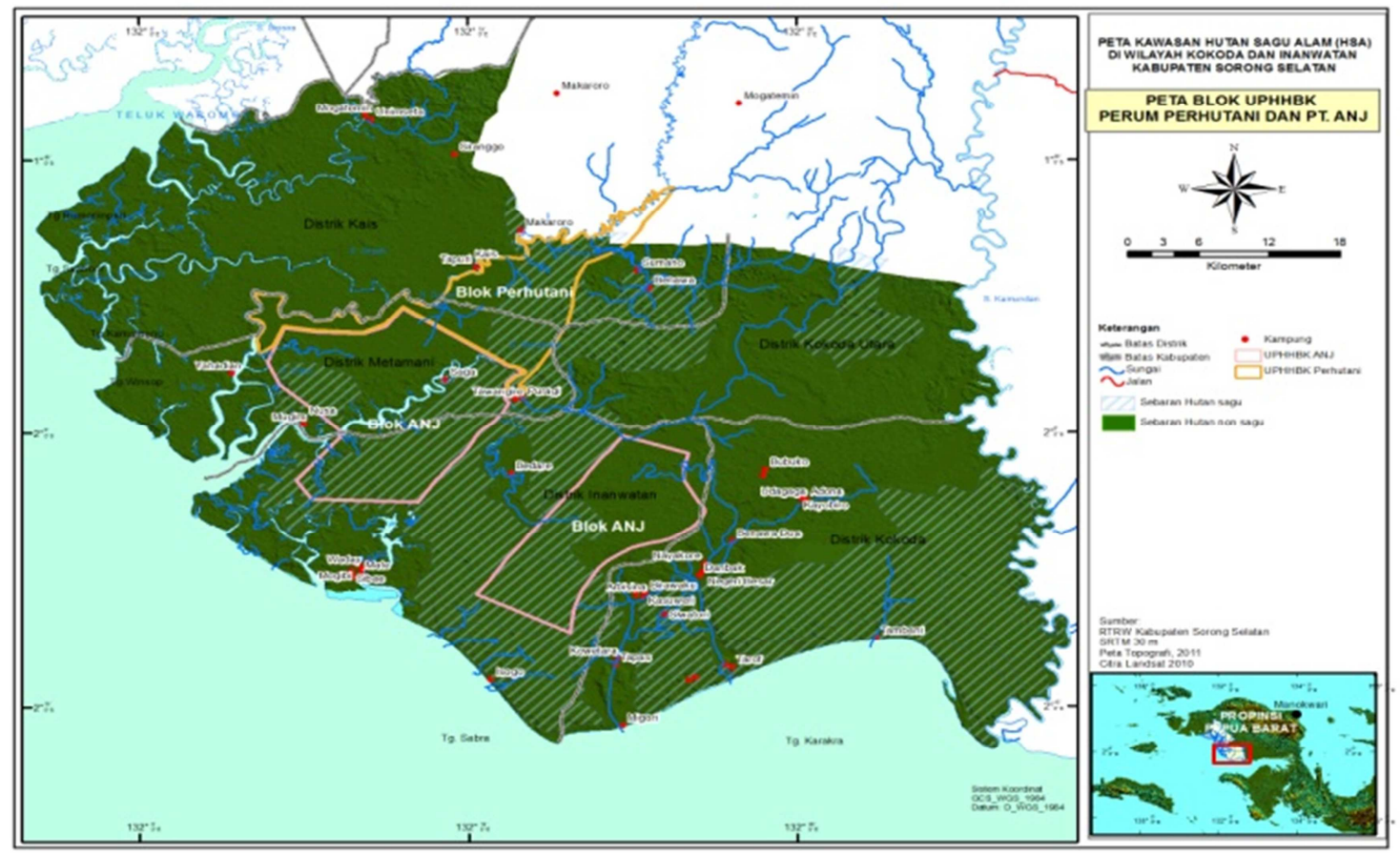

Figure 1. Map of research areas (South of Sorong Regency). 


\section{Result and Discussions}

\subsection{Structure of Customary Land Tenure of the NSF}

This section provide analysis of customary land tenure on the NSF in Imekko, including structure of land tenure rights, and patterns of land tenure inheritance.

\subsection{Structure of Land Tenure Rights}

It is commonly known that land tenure and properties right (e.g. forest and natural resources) in Papua belongs to communal ownership. This system stipulates tenure to be acquaired based on family name (keret/fam/marga), clans and kinships, and tribal groups. Generally, keret or family groups in certain areas has historical background. For example, member of keret Ugaje in Kasuweri Village, Kokoda District, claim that their achestors were actually from Fakfak Region who in fact migrated from Ternate and have been living in Fakfak for generations to date.

When first migrated, the anchestors of keret Ugaje claimed their ownership towards unoccupied lands. That ownership was then passed down to their decendants. Inheritance linehas become multiple due to growing human population. Members of the keret since then have claimed themselves as the owners of customary land rights over the area that is now called Kokoda District.

The status of customary land tenure here is similar to the land tenure practice in Javanese culture which is called yasan, yasa or yoso (Javanese Language). This means that one's right of ownership comes from his/her anchestors who were the ones to initially opened the lands or cultivated crops on the land $[13,15]$.

Land rights are acquired through legal status as established inthe 1960 Basic Agrarian Law (UUPA). In this case, member of keret Bawei, Giruri, Nuwaru, Karesogu, Tawerasaro, Weusaro, Udasarau, Mogu, Aitago, Rariaro, Sianuriago, and Oregago are the owners of customary land rights over theNSF in Saga. In Puragi-Tawanggire customary land rights belongs to member of keret Bobe, Gowae, Kaude, Bibigane, Idee, Daimar, Amee, Ajane, Rihe, Jare, Akore, Bumere, Orapae, Mengge, Gue, Kawaine, Amangine, Kadae, Mairerai, Dariane, Keime, Dobee, Bibireme, Korie, Manutune, Manas, Watarae, and Berae. In addition, rights over customary land in Bedare village belong to keretGiwa, Kabu, Sigeare, Abisai, Orie, Voaire, Asii, Dobore, Taipue, Udaire, and Saway. These keret are Iwaro by ethnicity.

In Kokoda, indigenous people and owners of customary land-rights and property rights act communally according to their ethnic groups: the Eme and the Awee. These communities classify themselves into old keret and young keret.

Old keret can be considered similar to yasa/yoso, the structure of land tenure and inheritance system in Javanese culture. In contrast, young keret refer to people who came and resided later in the area. Hence, the young keret sown less right on the land forest site comparing to the old ones'.
This status seems similar to the land management practice of norowito, gogolan, kekulen, playangan, or kesikepan in Javanese culture; which means that the land belongs to all members of young keret and they can be given rights to manage under certain criteria and conditions [14, 15].

Old keret, according to the local people, is like the upperclass society who owns full rights on the NSF sites in Kokoda District.

In fact, the old keret has absolute rights over the land access, collectingand harvesting forest products, use, control, manage, transferand relief (disposition) and reclamation and ownership. On the other hand, members of young keret usually have less rights and limited access than the old keret's. Thus, permission needs to be sought and acquired from the old groups if they intend to use and manage the land.

Majority of members of keret/fam - who are the dominant groups in each village are the keret with customary land rights towards all lands and the NSF sites around their villages. For instance, in Tapuri, the Awe and the Kaiso own rights over thelands and the NSF. Member of kerets under these two ethnic groups are Asikasauw, Nipai, Maginoni, Kabara, Kabere, Sira, Abago, Rairaro, Saimar, and Onim. In Kais village, the land tenure goes to these keret: Saimar, Abago, Kaitao, Asikasao, Sepa, Sira, and Budhi.

Given that land rights and ownership belong to family groups, it seems that naturally no individual ownership exists on the NSF. It is all communal and collective under keret/famstructure. Thiscommunal structure refere to firstly access right which means right to enter certain physical land border such as pathway or streams in NSF. Then, collecting forest product is right to harvest forets products such as sago starch, sago mushroom and worm. Next is right to use, means to utilize the area for planting subsiten crop (e.g. banana). Afterward, controlling is right to decide how the land will be used, wheter for plantation or natural forest. This right also enables the ownership to earn financial benefit from the NSF. Morover, managing right is right to organize the NSF for its utilization. Another is right transferand/or relief and reclamation which means right to sell or rent the property to others, and the last is ownershipis right to prosper NSF resources. Since it is communal, there can exist more than one keret/fam in one clan group. Meanwhile, on certain territorial borders that have previously been agreed, land right is collectively owned.

\subsection{Pattern of Land Use and Tenure}

Geographically, Imekko is far from Teminabuan, the capital of Sorong Selatan Regency. Access to its community is quite difficult and limited. Hence, land use for business, habitation, housing, and industry is unlikely to occur.

Traditionally, until the presenttime, it appears that the structure of land-forest tenure is still communal ownership based on keret/fam living in the area. Forest in Imekko can be categorized into two sites, customary Dusun Sago (sago forest that has been harvested before and is recultivated by 
the communities) that is more accessible and ready to use, and the NSF that is poorly located, far and/or inaccessible.

It should be noted, that it is not absolute that a community naturally owns the customary land rights over the NSF sites in the area they reside. In fact, it is reported that sometimes land rights owners reside in different villages. Such case can be observed in Saga village, where some members of keret own the rights over the NSF in Puragi and Tawanggire; and so does some kerets in Puragi and Tawanggire who own rights over the NSF site in Bedare village. A few members of keret in Bedare own right over the NSF located near the upstream of Metamani River (administratively located in Puragi and Tawanggire). Futhermore, apart from the NSF, parcels of Dusun Sagu are also found in and around NSF site.

Meanwhile, even though tenure pattern of the NSF is communal, its use is collective based on nuclear family and extended family setting. Family members can use of the NSFwhere they live in. On the other hand, collective pattern allow $1-3$ heads of household in one keret together with members of different keret to make an agreement of how to make use of the NSF sites around their villages and/or residency.

The pattern of land use on the NSF is collective. However, an ownership of sago forest is acquired through nuclear family members who are the descendants of people who grew and cultivated sago trees.

This research reveals that the NSF in Puragi and Tawanggire belongs to people of Saga. Structurally, Saga communities own the customary land rights over the NSF; but it is the people in Puragi and Tawanggire who own use and management rights of the NSF. Similarly, in Kais District, particularly people living in Siranggo, Makaroro, and Mogatemin enjoy de facto rights to make use of the the NSF on their land. The forest supports their basic needs, for example food and functions as their source of income. However, it is the people of Kais and Tapuri who own de jure right over the NSF. With regards to forest use, outsiders, people who are not originally from local community, have limited rights to access, use and collect forest products.

\subsection{Pattern of Land Tenure Inheritance}

Pattern of inheritance refers to rights of ownership on land resource and sago forest that is managed by one person with his family member $[13,15]$. This research found that tenure structure of the NSF in Imekko follows patrilinealstucture. Thus, the pattern of land inheritance follows this structure. It is known that besides the NSF, some Dusun Sagu are grown and cultivated by family groups, in either their own landforest site or others'. Dusun Sago is usually inherited from cultivators to their descendants under patrilineal structure.

In the entire locations, it was found that every keret/fam groups uses and/or owns a customary institution which is an indigenous territory. The institution is managed by one keret, who is considered senior by the communities. Right to govern the institution will be as well passed down through generations. In Sibae village, for example, land ownership and inheritance occur in patrilineal structure for four keret groups: Yawai, Ibau, Eridasaru, and Gusasara. Management of this institution is given and trusted to an individual for his status of being the eldest one. This person is the chief wholeads and coordinatesland ownership and property rights with members of the institution. Often times, the chiefis from the reference group: elder people who are highly respected in a keret/fam group. In Sibai village, Mr. Agustinus Yawai is chief of the customary instituion. In Kais and Tapuri village, Kais District, chief of the customary institution is Mr. Semuel Asikasao.

\subsection{Impacts of Industry Towards the Structure of Customary (Adat) Land Tenure}

The structure ofcustomary land tenure of the NSF in Imekko here were analyzed in relation to the emergence of PT ANJ-Agri Papua and Perum Perhutani.

\subsubsection{PT ANJ-Agri Papua}

PT ANJ - Agri Papua came to Imekko in 2007. Its main goal is to exploit the NSF throughsago starch industry. This factoryobtained its certificate of registration from Bupati (Head of Sorong Selatan Regency) through SK Bupati Kabupaten Sorong Selatan No. 103, 18 July 2008 concerning the granting ofNon-Timber Forest Product Utilization Permit (Ijin Usaha Pemanfaatan Hasil Hutan Bukan Kayu (IUPHBBK) - Sago) in natural forest, with concession area of 40,000 ha of Convertible Production Forest (Hutan Produksi yang dapat dikonversi) [6].

Owners of customary rights over the concession area of PT ANJ-Agri Papua are the Iwaro ethnic group. In particular, lists of keret/fam members with rights over the area are Orie, Dobore, Udaire, Mairerai, Deriane, Korie, Manas, Watarae, Berae, Bawey, Nuwaru, Karesogu, Tawerasaro, Weusaro, Udarasaru, Mogu, Aitago, Rariaro, Sinauriago, and Orerago. Meanwhile, local communities' responses towards PT ANJAgri Papuaare split: positive and negative. On the one hand, the factory benefits the communities. They earn more for living and have better welfare as the factory collects and buys sago logs from them. The communities can get the sago logs in and/or around the concession area, and later sell them off to the factory. They are paid based on how many logs they have. These logs are then turned into sago starch (flour).

On the other hand, it brings a disadvantage to the communities. Changes occur to their land tenure rights over the NSF, concession area of the factory. The companies have some restricted areas where are inaccessible to the local communities particularly, in terms of safety reason. Since company has been harvested sago logs almost everyday.

This research discovered numbers of keret/fam lose their customary rights over locations that become concession areas of the factory. Such keret are Manas, Bawey, Nuwaru, Karesogu, Tawerasaro, Weusaro, Udarasaru, Mogu, Aitago, Rariaro, Sinauriago, and Orerago. As a result, they depend only on particular sago forests under factory approval. It all depends on the factory's willingness for such commitment. For instance, the owners are not permited to cut down the living sago tree in the conssesionarea; they are only allowed 
to collect the broken sago logs that are not harvested by the company.

To sum up, under the initial structure settings of customary land tenure prior to the factory, local communities owns the rights of free access, harvest and crops, ownerships, landforest use and management, land disposition and repossession [5]. Nevertheless, when this research project was still ongoing, the 'absolute' rights over the same spots have been interfered and becomelimited after PT ANJ-Agri Papua operates and evolves. Nowadays, they have less and limited access to the sago forests, as well as to use and to collect forest products.

\subsubsection{Perum Perhutani}

Perum Perhutani obtained its Non-Timber Forest Product Utilization Permit (Ijin Usaha Pemanfaatan Hasil Hutan Bukan Kayu - IUPHBBK) on the Natural Sago Forest according to Bupati's Decree (SK Bupati Kabupaten Sorong Selatan) No. 522/223/BSS/XII Year 2012, on 14 December 2013. This factory owns land-forest use and management rights over approximately 16,055 ha [7].

The concession area of PerumPerhutani includes Kais, Tapuri, Makaroro, Sumano, and Benawa I in Kais District; and Saga, Puragi, and Tawanggire in Metemani District.

Based on Environment Impact Assessment, PerumPerhutani is highly likely to cause impacts on land use practice in community [7]. It is so as the factory will operate on the sites, which have been managed, utilized, and owned by local communities (owners of customary land tenure rights) for generations. They live by growing crops and do fishing in the forest area. In fact, some spots in the forests are considered sacred to the local communities.

Indeed, Perum Perhutani has made quite significant arrangements on its industrial sites. These, however, have led to changes in the pattern of customary land use and management. Hence, less and limited space is given to extract sago trees, hunt, grow crops, etc. There is a shift of land use from one keret to another administratively. In the short term, such case brings impacts on the patterns and routines of the community in terms of making use and managing the land-forest sites. In otherwords, it is highly likely that the local communities will have less and limited access to the sago forests in the concession area of the factories. Obtaining permit from the factory is now necessary.

Prior to Perum Perhutani emergence, the structure setting of customary land tenure allows local communities to gain free access, collecting forest products, land-forest use and management, land disposition and repossession, and ownerships. According to the communities, the case now is different that their rights over use, access and collecting forest products have become limited (only in the concession area of sago forests). In other words, they have less and limited control over their ancestral lands. The following presentscustomary land-forest tenure rights before and after.

Table 2. Collection of Customary Tenure Rights over the Natural Sago Forests (NSF) Before and After PT ANJ-Agri Papua and PerumPerhutani Established in Imekko, Sorong Selatan Regency.

\begin{tabular}{|c|c|c|c|}
\hline Property & Tenure Patterns & \multicolumn{2}{|l|}{ Bundle of Rights } \\
\hline-1 & -2 & \multicolumn{2}{|l|}{-3} \\
\hline \multicolumn{4}{|l|}{ Before } \\
\hline \multirow{7}{*}{ The Natural Sago Forest (NSF) } & \multirow{4}{*}{ Communal } & 1. access & 5. work and activities related to management process \\
\hline & & 2. collecting forest products & 6. transfer and relief ofcustomary land (land disposition) \\
\hline & & 3. use & 7. reclaim (land repossession) \\
\hline & & 4. control & 8. Ownership \\
\hline & \multirow{2}{*}{ Individual } & 1. access & 3. use \\
\hline & & 2. collecting forest products & 4. work and activities related to process of management \\
\hline & Communal & 1. access & \\
\hline \multirow{11}{*}{ Dusun Sagu (Sago Forests) } & \multirow{4}{*}{ Individual } & 1. access & 5. work and activities related to management process \\
\hline & & 2. collecting forest products & 6. transfer and relief of customary land (disposition) \\
\hline & & 3. use & 7. reclaimation (land repossession) \\
\hline & & 4. control & 8. ownership \\
\hline & \multirow{4}{*}{ Individual } & 1. access & 5. work and activities related to management process \\
\hline & & 2. collecting forest products & 6. transfer and relief of customary land (disposition_ \\
\hline & & 3. use & 7. reclaim (land repossession) \\
\hline & & 4. control & 8. ownership \\
\hline & \multirow{3}{*}{ Individual } & \multirow{3}{*}{\multicolumn{2}{|c|}{$\begin{array}{l}\text { 1. access } \\
\text { 2. collecting forest products on a limited basis } \\
\text { 3. limited use }\end{array}$}} \\
\hline & & & \\
\hline & & & \\
\hline \multicolumn{4}{|l|}{ After } \\
\hline The NSF in Factory Concession Area & $\begin{array}{l}\text { Communal and } \\
\text { Individual }\end{array}$ & \multicolumn{2}{|l|}{ 1. access } \\
\hline \multirow{5}{*}{$\begin{array}{l}\text { Customary Sago Forests inFactory } \\
\text { Concession Area }\end{array}$} & \multirow{5}{*}{$\begin{array}{l}\text { Collective and } \\
\text { Individual }\end{array}$} & \multicolumn{2}{|l|}{ 1. access } \\
\hline & & \multirow{2}{*}{\multicolumn{2}{|c|}{ 2. collecting forest products on a limited basis in village area in forest concession }} \\
\hline & & & 3. limited use \\
\hline & & \multicolumn{2}{|c|}{ 4. limited control } \\
\hline & & \multicolumn{2}{|c|}{ 5. limited work and activities related to management process } \\
\hline
\end{tabular}




\section{Conclusion}

The followings conclude and summarize the significant points of the research:

1. Naturally, customary land tenure over the Natural Sago Forest (NSF) in Imekko are own by communal and/or collective ownership based on keret/fam system. Communities are entitled with rights to: access, collect forest products, use, control, manage, transfer and/or release, reclaim, and own their land.

2. Ownership of non-local communities over the NSF can be acquaired by obtaining permission with or without compensation. In the case of using the forest for basic needs (e.g: food), and/or as source of family income (e.g: selling forest products), no compensation is needed. Ownership over the Dusun Saguis obtained through nuclear family memberswhose anchestors cultivated the sago forest.

3. Because of the emergence of PT ANJ Agri-Papua and Perum Perhutani, changes occur in customary tenure rights practised in Imekko. From eight (8), only three (3) rights that the communities retain under one condition: rights for accessing, collecting forest products, and using the forest. The condition that such practice can only be done in the village area of the forest concession plotted by the factories (using the forest for basic needs and assource of income). In addition, inheritance rights over Dusun Sagu forests are arranged under patrilineal line (descendants of cultivators).

\section{References}

[1] Fauzi, N. 2003. Be witness for reformation in Agraria: Base on The Local and Regional Demand. (Bersaksi untuk Pembaruan Agraria: Dari Tuntutan Lokal Hingga Kecenderungan Global) INSIST Press Printing. Jogyakarta.

[2] Hayami, Y. dan M. Kikuchi. 1987. Economic Troubles in Village: An Economic Approach on The Dynamic Of Organization in Asia (Dilema Ekonomi Desa: Suatu Pendekatan Ekonomi Terhadap Perubahan Kelembagaan di Asia). Yayasan Obor Indonesia. Jakarta.

[3] Jong, F. S. 1995. Research for the Development of Sago Palm (Metroxylon sagu Rottb.) Cultivation in Sarawak, Malaysia. Dept. Agriculture, Kuching, Sarawak, Malaysia. 139 p.

[4] Matanubun, H, L. Maturbongs. 2005. Sagu Palm Potential, Biodiversity Ang Socio-cultural Considerations for Industrial Sago Development in Papua, Indonesia. Di dalam: Sago Palm Development and Utilization. Proceeding of the Eighth International Sago Symposium. Jayapura, 4 - 6 Agustus. Manokwari: Root Crops ang Sago Research Center. The State University of Papua. Hlm 41-54.
[5] Numberi, F. 2011. Sagu; Potensi yang masih terabaikan. Bhuana Ilmu Populer. Jakarta.

[6] PPLH Unipa. 2008. Suitability Study on Plantation and Indutry of Sago in Kais, Inanwatan, and Kokoda Districs, South of Sorong Regency; (Studi Kelayakan Pengembangan Perkebunan dan Industri Sagu di Distrik Kais, Inanwatan, Kokoda Kabupaten Sorong Selatan) Collaboration between Environmental Study Center UNIPA and PT ANJ Agri-Papua Unpublished.

[7] PPLH Unipa. 2013. Environmental Impact Assessment: Planning of Non-Timber Forest Product Utilization on NSF and Sago Starch Industry (Analisis Dampak Lingkungan Hidup (ANDAL): Usaha Pemanfaatan Hasil Hutan Bukan Kayu pada Hutan Alam (UPHHBK-HA) Sagu dan Industri Pengolahan Pati Sagu) By: Perum Perhutani In Kais and Metamani Districts South of Sorong Regency, West Papua Province. Unpublished.

[8] Ruwiastuti, M. R. 2000. Deceive Insight; Political Law In Agraria; Break In The State Controls over Land Tenure Rights (Sesat Berpikir; Politik Hukum Agraria: Membongkar Alas Penguasaan Negara Atas Hak-Hak Adat); Insist Press; KPA dan Pustaka Pelajar. Yogyakarta.

[9] Sardjono, M. A. 2004. Mozaic of Sociological Forestry: Local Community, Politic and Resource Sustainability (Mosaik Sosiologi Kehutanan: Masyarakat Lokal, Politik dan Kelestarian Sumber-daya). Debut Press. Jogjakarta.

[10] Sitorus, M. T. F. 1998. Documentation Group of Social Science) (Kelompok Dokumentasi Ilmu-Ilmu Sosial) Published by IPB Bogor.

[11] Sugiyono. 2005. Memahami Penelitian Kualitatif. (Understanding of Qualitative Research) Alfabeta. Bandung.

[12] Syahyuti. 2006. 30 Valuable Concepts of Village and Agriculture Development: Description on Consept, Theory, Indicator and Variable (30 Konsep Penting dalam Pembangunan Pedesaan dan Pertanian: Penjelasan tentang Konsep, Istilah, Teori, dan Indikator serta Variabel). Jakarta: PT. Bina Rena Pariwara.

[13] Tjondronegoro, S. M. P. 1999a. Sociology of Agraria: Based on Best Writing Collection (SosiologiAgraria: Kumpulan TulisanTerpilih). Yayasan AKATIGA. Bandung.

[14] Tjondronegoro, S. M. P. 1999 . Green Revolution and Social Dynamic in Javeness Villages (Revolusi Hijau dan Perubahan Sosial di Pedesaan Jawa. Dalam Buku"Keping-keping Sosiologi Pede-saan."); Indonesia Higher Educational Department of. Jakarta.

[15] Wiradi, G. 1999. Problems on land Tenure Rights and Customary Law: Land Use Right and Indonesia Forest (Sekitar Masalah Hak Ulayat dan Hukum Adat pada Umumnya. Dalam: Hak Pengu-asaan Tanah dan Hutan Indonesia) Bogor, A Script on Community Forest Discussion, Forestry Faculty, Institut Pertanian Bogor.

[16] Yumte, Y. 2008. A Model for Estimating Starch Content of Wet Sago in South of Sorong Regency (Penyusunan Model Penduga Berat Basah Tepung Sagu Duri di Kabupaten Sorong Selatan. Bachelor Thesis, Forestry Faculty Institut Pertanian Bogor. Unpublished. 